\title{
Analysis of Customer Value, Satisfaction and Loyalty of Recommendation Behavior in Digital Payment Applications: Case Study of Gopay and OVO
}

\author{
Rachma Rizqina Mardhotillah $^{1 *}$, Berto Mulia Wibawa ${ }^{2}$ Moch Afiff Muhggni Labib ${ }^{2}$ \\ Denis Fidita Karya ${ }^{1 *}$
}

${ }^{1}$ Department of Management, Nahdlatul Ulama University of Surabaya, Indonesia

${ }^{2}$ Department of Business Management, Institut Teknologi Sepuluh Nopember, Indonesia

*Corresponding author. Email: rachma.rizqina@unusa.ac.id

\begin{abstract}
The development of the use of digital payment is currently very rapid. Gopay and OVO are two of the digital payment service providers that are currently the most widely used by Indonesian people with evidence of data showing 2 digital payment users are quite high, although as we have seen, there are still many other digital payments that are quite competitive in the past. now. This study aims to see how ways to create customer value can influence customer satisfaction and loyalty improvement and provide behavioral recommendations that can be used as key success factors for digital payment services. The first method used in this research is exploratory research with data collection techniques using in-depth internet research data. While the second method is conclusively descriptive multiple cross-sectional by distributing online questionnaires to 408 samples with GoPay and / or OVO criteria in the age range of 17-45 years and having transacted in the past month. Then the data will be processed using a comparison between Semantic Differential and Structural Equation Modelling (SEM). The results of the analysis using the semantic differential method showed that GoPay was rated higher than OVO. Whereas the analysis using SEM method shows satisfaction, loyalty and interest in recommendations that have positive influence so that each factor that is considered to be able to meet the requirements of interest recommendations can have a positive effect and can directly create a recommendation behavior for digital payment users.
\end{abstract}

Keywords: Digital Payment, GoPay, OVO, Customer Value, Recommendation Behavior.

\section{INTRODUCTION}

While the competition in the mobile payment industry is getting more competitive, it can be seen from the emergence of various new players in the industry. Demonstrates the importance of knowing competition in the analysis of competitor maps in the mobile payment industry. This is useful for identifying and defining competitors based on their offering category. In the midst of a competitive industry, there is intense competition between mobile payment service providers, namely GoPay and OVO, which are the most popular mobile payment applications in Indonesia. The competition between Go-Pay and OVO makes the differentiation felt by consumers low, so it is important for the two services to compare the advantages and disadvantages based on an 
assessment from the consumer's point of view. In addition, to overcome the increasing bargaining power of consumers, it is very important to know how the postadoption behaviour of Go- Pay and OVO users can be seen from the recommendation interest based on customer value, level of satisfaction and level of customer loyalty. So that it can be evaluated the success rate of the mobile payment service provider of customer recommendation behaviour. The first objective of this research is Investigating competitor maps in mobile payment services so that competition can be identified in the mobile payment industry. The second objective is to analyze the profile comparison between two mobile payment applications, namely Go-Pay and OVO to find out the advantages and disadvantages of the two applications. And the third objective is to analyze the effect of customer assessment, level of satisfaction and level of loyalty on interest in recommendations to improve post-adoption behaviour in the use of GoPay and OVO mobile payment services.

\section{LITERATURE REVIEW}

Mobile payment is defined as a payment system for goods, services and various kinds of bills using mobile devices such as smartphones and other digital devices using wireless communication technology [1]. Meanwhile, according to [2] defines the concept of mobile payment which is a process in which at least one phase of transactions is carried out using mobile devices (such as cell phones, smartphones and other wireless devices) which are capable of processing financial transactions securely via cellular networks. or through various wireless technologies (such as NFC, bluetooth, QR code and other technologies).

Customer Perceived value describes the value desired when using the services offered [3]. And according to Zeithaml [4] Customer value is defined as a consumer's overall assessment of the utility of a product based on perceptions of what is received and what is given. Perceived value is a popular concept in the study of consumer behavior, and this concept expresses evaluation based on the benefits offered, compared to the sacrifices that consumers make to obtain and use a product or service [5].

According to Venkatesh et al. [6] defined utility benefits as functional benefits obtained when using mobile payment services, these benefits are a form of application performance that plays a role in achieving desired results by users. Meanwhile, according to Kerviler et al. [3] the utilitarian benefit value is the result of the expected performance using mobile payment services. The utility system factor or use in mobile payment is shown to what extent someone believes that using a mobile payment system will provide superior and desirable results [6]. In other words, the usefulness of the system reflects a behavior-based belief about the consequences of using the system [7]. In his explanation, System utility reflects the utilitarian benefits of using an information system and represents the perceived usefulness factor in the Technology Acceptance Model (TAM) theory and expected performance in UTAUT [8].

System quality or system quality is an object-based perceived belief in a system or application. When referring to the research of $\mathrm{Xu}$ et al. [7] system quality will be stated as application quality. If according to the conceptual Wixom \& Todd [9] system quality reflects such as system reliability, system responsiveness and system integration of smartphones as a payment medium itself. The quality of the system itself is also important for user behaviour, because if the mobile payment system is difficult to use, users may feel that the service provider lacks the ability and integrity to offer quality services.

In addition to the utilitarian benefits used to determine the formation of value characteristics in customers. There are benefits from another point of view, namely the hedonic benefits. According to Xu et al. [7] that hedonic benefits can be referred to as external benefits because they are defined as non- functional benefits provided by the performance of a service to get pleasure and selfsatisfaction. Hedonic benefits are obtained by a user because they arise from feelings or affective states generated by mobile payment services [6].

Enjoyment or convenience is the extent to which users in using a service can please themselves, regardless of the consequences of the service's performance. Various IS studies show that convenience directly affects technology acceptance and interest in use [10]. The enjoyment factor used in the study strongly reflects the hedonic benefits of using the UTAUT 2 theory and the Motivation Model of IT Adoption theory [11].

Aesthetics is a guideline that must be considered in designing the display system in an information system. So aesthetics is an object-based belief about the visual appearance of a system. Previous research on information systems has shown that system aesthetics play a decisive role in influencing users to adopt various types of information technology categories. The effect of aesthetic systems on technology user behaviour can be explained through many theories such as The Signalling Theory, and The Visual Rhetoric Theory[12].

Price is an important component in terms of the financial costs required to obtain and use a product / service. Perceived price or price that is felt is a result of grouping prices on products / services based on customer assessments with the intention that it is meaningful to these customers[4]. Much of the literature on marketing shows that perceived price affects the value perceived by customers. If the price of an item is unacceptable or beyond the customer's ability, the customer will assume that the product has little or no value.

Privacy risk is a major consumer problem in adopting 
mobile payments because a lot of personal information such as telephone numbers, pin codes, location and historical data of purchases etc. are needed in the use of mobile payment services [13]. Perceptions of the possibility of exposure to other parties about users' personal information are referred to as privacy risks [14] Meanwhile, according to Sweeney et al. [15] Privacy risk refers to malicious behavior on the part of an application developer regarding the collection and use of individual information about application users.

Knowledge of alternative quality or knowledge of alternative quality can be defined to what extent users realize that there are alternative mobile payment application services that are better at meeting needs, when compared to the application services used [7]. The concept of knowledge of alternative quality is based on The Relationship Perspective of Marketing theory and The Commitment and Trust Model of IT Continuance [16]. Both theories indicate that the intention to continue using information technology also depends on the quality of the alternative products offered by competitors.

Technicality or technical factors are defined as the extent to which mobile payment application service users consider technically that the service is technically difficult to use [7]. Based on the theory of the valuebased adoption model of technology [17]. The technical factor is a non-monetary sacrifice in using an information system service. In the context of mobile payment application services, technicality is categorized as high if it is associated with too complex a system, or requires special understanding in operating the system. So based on the explanation from previous research, the technicality factor is a significant factor in non-monetary sacrifices [7].

Satisfaction is a key factor in the VSL model. Satisfaction or satisfaction is a form that reflects feelings that can change and develop cumulatively when customers get the desired value when interacting with service providers [18]. Satisfaction can also be said to be the key to fostering and maintaining loyal customers, because satisfaction is the main factor as the main result of marketing activities, and is very influential in changing consumers' initial perceptions to make repeated purchases or use or it can be said to form consumer loyalty [7].

Continuance intention or interest in continuous use is classified as post adoption of mobile payment services and post-adoption use is one of the important factors in determining the success of mobile payment service providers [18]. Continuance intention is defined as consumer interest as individual users who reflect their willingness to continue using a service [7].

Interest in making recommendations is a form of communication that allows users to express their opinions and experiences about mobile payment services to others [19]. Interest in recommendations can be indicated that consumers with higher intentions of sustainable use are likely to make recommendations to the community in the surrounding environment [20].

\section{METHODS}

The research design used consists of two ways, first, namely exploratory research to identify competitive conditions through competitor map analysis with indepth internet search data collection techniques. The results showed that as many as 56 companies were declared direct competitors and 35 companies were declared indirect competitors, so it can be said that the mobile payment industry currently has a very high level of competition. The second research method uses conclusive descriptive multiple cross-sectional with data collection techniques using online questionnaires. The online questionnaire was distributed to 408 samples who were Go-Pay and / or OVO users and had made transactions in the last one month with an age range of 17-45 years. Furthermore, the data were analyzed using a comparison of semantic differential and Structural Equation Modelling (SEM).

\section{RESULT}

The researcher conducted a structural model analysis of the planned research model. Structural model testing is useful for determining the relationship between variables to answer the research hypothesis. Before testing the hypothesis, a structural fit model test must be carried out to determine the feasibility of the structural model. The structural fit model test is carried out through a comparative analysis of the results of the fit model obtained with the cut- off value criteria of the goodness of fit model based on the theory [21]. 
Table 1. Criteria of the goodness of fit model

\begin{tabular}{|c|c|c|c|c|c|c|c|c|}
\hline \multirow[t]{2}{*}{ No } & \multirow{2}{*}{$\begin{array}{c}\text { Goodness } \\
\text { Of Fit } \\
\text { Measure }\end{array}$} & \multirow{2}{*}{$\begin{array}{c}\text { Cut- } \\
\text { off } \\
\text { Value }\end{array}$} & \multicolumn{2}{|c|}{$\begin{array}{c}\text { Sebelum } \\
\text { Respesifikasi }\end{array}$} & \multirow{2}{*}{$\begin{array}{l}\text { Cut- } \\
\text { off } \\
\text { Value }\end{array}$} & \multicolumn{2}{|c|}{$\begin{array}{c}\text { Setelah } \\
\text { Respesifikasi }\end{array}$} & \multirow[t]{2}{*}{ Sumber } \\
\hline & & & Nilai & Keterangan & & Nilai & Keterangan & \\
\hline \multicolumn{9}{|c|}{ Absoulute Fit Indische } \\
\hline 1 & CMIN/DF & $\leq 3$ & 3,040 & Tidak Fit & $\leq 3$ & 2,490 & Fit & $\begin{array}{l}\text { (Wijanto, } \\
2008 \text { ) }\end{array}$ \\
\hline 2 & GFI & $\geq 0,9$ & 0,715 & Tidak Fit & $0,7-0,8$ & 0,766 & Fair & $\begin{array}{l}\text { (Peng \& } \\
\text { Fuzhou, 2015) }\end{array}$ \\
\hline 3 & AGFI & $\geq 0,9$ & 0,687 & Tidak Fit & $0,7-0,8$ & 0,739 & Fair & $\begin{array}{l}\text { (Peng \& } \\
\text { Fuzhou, 2015) }\end{array}$ \\
\hline 4 & RMR & $\leq 0,08$ & 0,172 & Tidak Fit & $\leq 0,08$ & 0,171 & Tidak Fit & $\begin{array}{l}\text { (Malhotra, } \\
\text { 2009) }\end{array}$ \\
\hline 5 & RMSEA & $\leq 0,08$ & 0,072 & Fit & $\leq 0,08$ & 0,061 & Fit & $\begin{array}{l}\text { (Malhotra, } \\
\text { 2009) }\end{array}$ \\
\hline \multicolumn{9}{|c|}{ Incremental Fit Indische } \\
\hline 6 & NFI & $\geq 0,9$ & 0,823 & Tidak Fit & $0,8-0,9$ & 0,858 & $\begin{array}{l}\text { Marginal } \\
\text { Fit }\end{array}$ & $\begin{array}{l}\text { (Wijanto, } \\
\text { 2008) }\end{array}$ \\
\hline 7 & CFI & $\geq 0,9$ & 0,873 & Tidak Fit & $\geq 0,9$ & 0,909 & Fit & $\begin{array}{l}\text { (Malhotra, } \\
\text { 2009) }\end{array}$ \\
\hline 8 & IFI & $\geq 0,9$ & 0,874 & Tidak Fit & $\geq 0,9$ & 0,910 & Fit & $\begin{array}{l}\text { (Malhotra, } \\
\text { 2009) }\end{array}$ \\
\hline 9 & TLI & $\geq 0,9$ & 0,866 & Tidak Fit & $\geq 0,9$ & 0,902 & Fit & $\begin{array}{l}\text { (Malhotra, } \\
\text { 2009) }\end{array}$ \\
\hline \multicolumn{9}{|c|}{ Persimony Fit Indische } \\
\hline 10 & PNFI & $\begin{array}{l}0,60- \\
0,90\end{array}$ & 0,778 & Fit & $\begin{array}{l}0,60- \\
0,90\end{array}$ & 0,796 & Fit & $\begin{array}{l}\text { (Wijanto, } \\
2008 \text { ) }\end{array}$ \\
\hline 11 & PGFI & $\begin{array}{l}0,50- \\
1,00\end{array}$ & 0,652 & Fit & $\begin{array}{l}0,50- \\
1,00\end{array}$ & 0,686 & Fit & $\begin{array}{l}\text { (Wijanto, } \\
\text { 2008) }\end{array}$ \\
\hline
\end{tabular}

After the respecification stage is carried out, it is shown in the table above that there is a change in the GOF value for the better as indicated by the increase in the value that meets the cut-off-value criteria. In the results of the researcher's respesification also conducted a literature study to support the results of the model being said to be feasible. When compared with the GOF value before respecification, from the total criteria for goodness of fit, there are seven criteria categorized as fit, one criterion is categorized as marginal fit and two criteria are categorized as fair. Fair results refer to research by Peng $\&$ Fuzhou [22] and marginal fit results refer to Wijanto which states that if a model has GFI, AGFI, NFI, CFI and TLI values $\geq 0.7$ and $\geq 0.8$ then the model is still considered feasible, and allowed to proceed to the next stage of analysis. 
Table 2. Hypothesis test conducted using path analysis in Structural Equation Modelling (SEM).

\begin{tabular}{|c|c|c|c|c|c|c|c|}
\hline \multicolumn{2}{|c|}{ Hipotesis } & \multicolumn{2}{|c|}{ Pengaruh } & $\begin{array}{l}\text { Standardized } \\
\text { Regression } \\
\end{array}$ & \multirow{2}{*}{$\begin{array}{c}p- \\
\text { value } \\
\text { *** }\end{array}$} & \multirow{2}{*}{$\begin{array}{l}\text { Keterangan } \\
\text { Signifikan }\end{array}$} & \multirow{2}{*}{$\begin{array}{c}\text { Hasil } \\
\text { Diterima }\end{array}$} \\
\hline Hla & Satisfaction & $\rightarrow$ & $\begin{array}{l}\text { Continuance } \\
\text { Intention }\end{array}$ & e $\quad 0,438$ & & & \\
\hline $\mathrm{Hlb}$ & Satisfaction & $\rightarrow$ & $\begin{array}{l}\text { Intention to } \\
\text { Recommen- } \\
\text { dation }\end{array}$ & 0,194 & 0,006 & Signifikan & Diterima \\
\hline $\mathrm{H} 2 \mathrm{a}$ & $\begin{array}{l}\text { Non- } \\
\text { Monetary } \\
\text { Sacrifices }\end{array}$ & $\rightarrow$ & $\begin{array}{l}\text { Continuance } \\
\text { Intention }\end{array}$ & $-0,124$ & 0,013 & Signifikan & Diterima \\
\hline $\mathrm{H} 2 \mathrm{~b}$ & $\begin{array}{l}\text { Non- } \\
\text { Monetary } \\
\text { Sacrifices }\end{array}$ & $\rightarrow$ & $\begin{array}{l}\text { Intention to } \\
\text { Recommen- } \\
\text { dation }\end{array}$ & $-0,129$ & 0,009 & Signifikan & Diterima \\
\hline $\mathrm{H} 3 \mathrm{a}$ & $\begin{array}{l}\text { Perceived } \\
\text { Price }\end{array}$ & $\rightarrow$ & $\begin{array}{l}\text { Continuance } \\
\text { Intention }\end{array}$ & 0,138 & 0,002 & Signifikan & Ditolak \\
\hline $\mathrm{H} 3 \mathrm{~b}$ & $\begin{array}{l}\text { Perceived } \\
\text { Price }\end{array}$ & $\rightarrow$ & $\begin{array}{l}\text { Intention to } \\
\text { Recommen- } \\
\text { dation }\end{array}$ & $-0,011$ & 0,808 & $\begin{array}{l}\text { Tidak } \\
\text { Signifikan }\end{array}$ & Ditolak \\
\hline $\mathrm{H} 4 \mathrm{a}$ & $\begin{array}{l}\text { Utilitarian } \\
\text { Benefit }\end{array}$ & $\rightarrow$ & $\begin{array}{l}\text { Continuance } \\
\text { Intention }\end{array}$ & 0,110 & 0,019 & Signifikan & Diterima \\
\hline $\mathrm{H} 4 \mathrm{~b}$ & $\begin{array}{l}\text { Utilitarian } \\
\text { Benefit }\end{array}$ & $\rightarrow$ & $\begin{array}{l}\text { Intention to } \\
\text { Recommen- } \\
\text { dation }\end{array}$ & $-0,133$ & 0,004 & Signifikan & Ditolak \\
\hline $\mathrm{H} 5 \mathrm{a}$ & $\begin{array}{l}\text { Hedonic } \\
\text { Benefit }\end{array}$ & $\rightarrow$ & $\begin{array}{l}\text { Continuance } \\
\text { Intention }\end{array}$ & 0,271 & $* * *$ & Signifikan & Diterima \\
\hline $\mathrm{H} 5 \mathrm{~b}$ & $\begin{array}{l}\text { Hedonic } \\
\text { Benefit }\end{array}$ & $\rightarrow$ & $\begin{array}{l}\text { Intention to } \\
\text { Recommen- } \\
\text { dation }\end{array}$ & 0,336 & $* * *$ & Signifikan & Diterima \\
\hline H6 & $\begin{array}{l}\text { Non- } \\
\text { Monetary } \\
\text { Sacrifices }\end{array}$ & $\rightarrow$ & Satisfaction & $-0,075$ & 0,124 & $\begin{array}{l}\text { Tidak } \\
\text { Signifikan }\end{array}$ & Ditolak \\
\hline $\mathrm{H} 7$ & $\begin{array}{l}\text { Perceived } \\
\text { Price }\end{array}$ & $\rightarrow$ & Satisfaction & 0,256 & $* * *$ & Signifikan & Ditolak \\
\hline H8 & $\begin{array}{l}\text { Utilitarian } \\
\text { Benefit }\end{array}$ & $\rightarrow$ & Satisfaction & 0,315 & $* * *$ & Signifikan & Diterima \\
\hline H9 & $\begin{array}{l}\text { Hedonic } \\
\text { Benefit }\end{array}$ & $\rightarrow$ & Satisfaction & 0,575 & $* * *$ & Signifikan & Diterima \\
\hline $\mathrm{H} 10$ & $\begin{array}{l}\text { Continuance } \\
\text { Intention }\end{array}$ & $\rightarrow$ & $\begin{array}{l}\text { Intention to } \\
\text { Recommen- } \\
\text { dation }\end{array}$ & 0,339 & $* * *$ & Signifikan & Diterima \\
\hline H11 & $\begin{array}{l}\text { Intention to } \\
\text { Recommend } \\
\text { ation }\end{array}$ & $\rightarrow$ & $\begin{array}{l}\text { Recommen- } \\
\text { dation }\end{array}$ & 0,845 & $* * *$ & Signifikan & Diterima \\
\hline
\end{tabular}

From the results of the relationship between satisfaction with interest in sustainable use and interest in recommendations, the results are consistent with previous research. Research conducted by $\mathrm{Xu}$ et al. [7] and Ranaweera \& Prabhu [23] which also show that satisfaction has a positive influence on two post-adoption purchasing behaviour, namely re-purchase and interest in doing word of mouth. $\mathrm{Xu}$ et al. [7] explained that satisfaction does have a significant effect on consumer loyalty in terms of interest and behaviour. There are two types of loyalty in consumer behaviour, namely customer retention which is presented with interest in sustainable use and customer attraction which is presented with interest in user recommendations.

From this relationship, it can be seen that user satisfaction can be used as one of the keys to maintaining a long-term relationship between service providers and users [24]. Satisfaction is a form of feeling that indicates that someone has got the desired value from a service. So that if a satisfaction has emerged, it can tend to make consumers continue to use the same service again. In addition, consumer satisfaction can also encourage users to spread positive things related to services used to others
[25]. This is a very beneficial impact if the company can shape customer satisfaction. Another fact states that users who are very satisfied with the overall condition and feel happy about a service can significantly increase user loyalty and interest in making word of mouth recommendations than users who are only satisfied [19].

From these results it can be seen that non-financial sacrifices are stated to have a direct influence on the interest in using the mobile payment application on an ongoing basis and the interest in making recommendations. For testing hypothesis $2 \mathrm{a}$, there are similarities in the results of the study between this study and research by $\mathrm{Xu}$ et al[7]related the relationship between non-financial sacrifice and interest in sustainable use. This is also in accordance with expectations and related theories, which discuss that the sacrifices a user makes in adopting a system can affect the perceived value of user interests and behaviour in adopting a system [26].

According to $\mathrm{Xu}$ et al. [7] explained that there was no significant influence between non-financial sacrifice and interest in recommendations, because based on the literature from Matos \& Rossi [27] it was revealed that 
the sacrifice factor only had an indirect effect on the interest in doing word of mouth. However, in this study, the proposed hypothesis is acceptable, thus indicating that in the use of mobile payments, non-financial risks such as technical risks and privacy are very important considerations for someone to engage in sustainable use interest and recommendation interest. When viewed from current conditions, the use of mobile payments such as Go-Pay and OVO is a financial technology application in which there are various important information and user finances. If the privacy and technical risks felt by users are increasing, such as the possibility of users' personal data being stolen and application systems that are increasingly complex to use, of course users will feel insecure and uncomfortable to use the service continuously [28]. This is very different from the effect on the satisfaction variable because users are only concerned with profit and paying less attention to risk.

The results of the hypothesis test findings obtained have differences and similarities with previous research. In a study conducted by Xu et al. [7] and Pham \& Ho [29] show that perceived price / cost does not have a significant effect both on interest in sustainable use and interest in recommendations. Because the perceived price has a very small role in shaping the behaviour of adopting mobile payments, hypothesis $3 \mathrm{~b}$ is stated in accordance with previous research, that there is no direct influence between perceived price and interest in recommendations. However, there is a positive mediating effect between perceived price through satisfaction and loyalty to interest in recommendations.

According to Venkatesh et al [6] price value is a positive perception of the price offered because a service provider provides more benefits at a very low cost. So that the price value makes the perceived price low because there are many promotions and discounts offered. This is in accordance with current conditions where Go-Pay and OVO offer a lot of discounts and promotions so that the price that is felt when making transactions is cheap. With the massive discount war by service providers, users perceive the perceived price to be low and profitable for the user. This assumption makes perceived price a price value obtained through the use of Go-Pay and OVO. The high price value certainly makes users more interested in continuing to use mobile payments.

This study has similarities to the study of $\mathrm{Xu}$ et al. [7]stated that utilitarian benefits in the form of system quality and utility systems have a direct influence on the interest in using applications in a sustainable manner. In addition, according to Pham \& Ho [29], the perceived benefits are the most influential influence on the adoption behaviour of the use of mobile payments. As well as utilitarian benefits also have indirect benefits that are mediated through satisfaction, this is also in line with research conducted by Zhou [18]. Utilitarian benefits that show the functional side of the system are strong predictors for building positive value on a system service, especially mobile payments. So that making utilitarian benefits is an important factor in improving user postadoption behaviour.

From this test, it shows that the benefits of hedonic are a very strong predictor of increasing loyalty and interest in recommendations. These results are similar to the research conducted by $\mathrm{Xu}$ et al. [7] with the results that hedonic benefits have a direct positive effect on continued user interest and significant recommendation interest. In addition, the research results are also in accordance with the research by Rouibah et al. [30] who stated that perceived enjoyment can increase user trust and adoption behaviour.

These findings are very rational in the current condition of mobile payment usage in Indonesia. Due to the fact that the use of mobile payment applications tends to be new, the majority of service providers will provide promotions and large discounts to increase public interest in mobile payment applications. This has made people ignore the perceived non-financial sacrifices because they consider the value of the discount offered to be more valuable than the perceived risk. This is in line with the statement of Kim et al. [17] which states that if the benefits in terms of the price received are very high, the sacrifices incurred will not be felt. In addition, they consider the use of mobile payments as a new financial technology service, so that people tend to be more willing to try something new so that they ignore the risks that may arise.

The effect of the relationship on these variables has different results from previous studies conducted by $\mathrm{Xu}$ et al. [7]who showed positive results but were declared insignificant, this was because the objects used in this study were different from previous studies. Kim et al. [31] explained that the occurrence of an insignificant positive effect was made possible by several factors, namely, the application used offered a low price and the application had other advantages so that the price had no effect. Similar to the effect of perceived price on sustainable use, the positive effect of price value on satisfaction is obtained because the prices offered by mobile payment service providers are low, resulting in price value [19]. So that the price perceived by mobile payment users now has a positive effect on satisfaction.

These findings have similarities with previous research conducted by [7] which states that utilitarian benefits have a direct positive effect on application user satisfaction. The utilitarian benefit is a functional benefit that is a value of excellence in mobile payment services, utilitarian benefits can further encourage user satisfaction if the performance of the service is as expected. This is very relevant because consumer satisfaction is actually the result of user value that is formed from perceived 
benefits [32]. According to Lam [25], it is stated that customer value or in this study is a utilitarian benefit and hedonic benefits act as a cognition construct which is assessed as a predictor to encourage the level of consumer satisfaction.

These findings have similarities with previous studies conducted by $\mathrm{Xu}$ et al. [7] and Chaabane \& Volle [33] which state that hedonic motivation is the strongest predictor of directly influencing user satisfaction. Hedonic motivation is a social benefit or external benefit outside of the perceived functionality of the system, which creates pleasure and happiness when using technology, especially in mobile payments [19]. The hedonic benefit variable in this study has the same role as the utilitarian benefit, which reflects customer value by becoming a cognition construct in directly affecting satisfaction. The relationship between hedonic benefits and satisfaction is also assessed as a mediating relationship that is useful for predicting the indirect relationship between user interest in making recommendations. Satisfaction is very importance for business impact [34] and [35].

Interest in sustainable use is a sign as a perspective of consumer loyalty in the context of the use of behavioural information technology that describes affective behaviour from the results of user value and satisfaction [36]. Matos \& Rossi, [27] states that the behaviour of word of mouth in users is associated with users who are loyal to a product or service. So that the loyalty factor is considered a factor that directly influences user interest in making recommendations [35].

Interest in making recommendations is a form of communication that allows users to express their opinions and experiences about mobile payment services to others [19]. In this study, recommended behaviour testing was carried out to examine the actual action of post-adoption behaviour of mobile payment users. so that it can be used as a critical success factor for service providers. From the results of hypothesis testing that has been done, there are similarities in the results with previous research. $\mathrm{Xu}$ et al[7] stated that there is a positive influence between recommendation interest on recommendation behaviour, indicating that recommendation interest is influenced by customer value, satisfaction and loyalty plays an active role in improving recommendation behaviour for Go-Pay and OVO users.

\section{CONCLUSION}

The results of the analysis of the competitor map for mobile payment service providers in Indonesia, it is known that the current conditions of competition between service providers are very high and competitive. The level of competition indicates that there are 56 financial technology companies in the payment sector that offer server-based e-money systems with similar characteristics and payment activities to be categorized as direct competitors. In addition, there are 35 services that offer the use of e-money with almost the same payment activities but have different characteristics which are categorized as indirect competitors.

the results of the semantic profile comparison analysis based on the ratings of each Go-Pay and OVO service users. Of the 15 attribute factors in the assessment, it is known that Go-Pay is considered superior to OVO on 13 attribute factors (ease of use, system practicality, attractiveness of appearance, newness of service, app suitability, system quality, speed of time, service trust, system security, diversity. features and services, number of merchants, and level of promotion) although the value obtained between the two services does not differ significantly. Meanwhile, the advantages of OVO over Go-Pay are only superior to two attribute factors (cheaper transaction prices and higher reward points).

The results of the analysis of structural equation modelling (SEM) show that there are several customer values that are divided into benefits and sacrifice variables that can directly influence post-adoption behaviour in the use of mobile payment applications. First, perceived utilitarian benefits are considered to have a positive effect on satisfaction and loyalty perspectives. Second, the perceived hedonic benefits are considered to have a positive effect on satisfaction, the perspective of loyalty and interest in recommendations. Third, perceived monetary or price sacrifices have a positive effect on user satisfaction and loyalty, because many discount promotions and cashbacks are offered. Fourth, non-financial sacrifices are considered to have a negative effect on loyalty and interest in recommendations. Also, every post-adoption behaviour, namely satisfaction, loyalty and interest in recommendations, is considered to have a positive relationship.

\section{REFERENCES}

[1] T. Dahlberg, N. Mallat, J. Ondrus, and A. Zmijewska, "Past, Present and Future of Mobile Payments Research: A Literature Review," Electron. Commer. Res. Appl., vol. 7, no. 1, pp. 165-181, 2008.

[2] A. Ghezzi, F. Renga, R. Balocco, and P. Pescetto, "Mobile Payment Applications," Offer State Art Ital. Mark., vol. 12, no. 5, pp. 3-22, 2010.

[3] G. de Kerviler, N. Demoulin, and Z. Pietro, "Adoption Of In-store Mobile Payment: Are Perceived Risk And Convenience The Only Drivers?," J. Retail. Consum. Serv., vol. 31, pp. 334-344, 2016.

[4] V. A. Zeithaml, "Consumer perceptions of price, quality, and value: a means-end model and synthesis of evidence," J. Mark., vol. 52, no. 3, pp. 
2-22, 1988.

[5] W. Ulaga, "Capturing value creation in business relationships : a customer perspective," Ind. Mark. Manag., vol. 32, no. 8, pp. 677-693, 2003.

[6] V. Venkatesh, J. Y. L. Thong, and X. Xu, "Consumer acceptance and use of information technology: extending the unified theory of acceptance and use of technology," MIS Q., vol. 36, no. 1, pp. 157-178, 2012.

[7] C. Xu, D. Peak, and V. Prybutok, "A Customer Value, Satisfaction, and Loyalty Perspective of Mobile Application Recommendations," Decis. Support Syst., vol. 79, no. 1, 2015, doi: 10.1016/j.dss.2015.08.008.

[8] F. D. Davis, "Perceived usefulness, perceived ease of use, and user acceptance of information technology," MIS Q., vol. 3, no. 13, pp. 319-340, 1989.

[9] B. H. Wixom and P. A. Todd, "A theoretical integration of user satisfaction and technology acceptance," Inf. Syst. Res., vol. 16, no. 1, pp. 85$102,2005$.

[10] H. van der Heijden, "User Acceptance of Hedonic Information Systems," MIS Q., vol. 28, no. 4, pp. 695-, 2004.

[11] F. D. Davis, R. P. Bagozzi, and P. R. Warshaw, "Extrinsic and Intrinsic Motivation To Use Computers in The Workplace," J. Appl. Soc. Psychol., vol. 22, no. 14, pp. 1111-1132, 1992.

[12] J. D. Wells, J. S. Valacich, and T. J. Hess, "What signal are you sending? How website quality influences perceptions of product quality and purchase intentions," MIS Q., vol. 2, no. 2011, pp. 18-373, 2011.

[13] Y. Yang, Y. Liu, H. Li, and B. Yu, "Understanding perceived risks in mobile payment acceptance," Cluster Innovation Performance Based on SEM Simulation," in International Symposium on Computers \& Informatics, 2015, pp. 1226-1231.

[23] C. Ranaweera and J. Prabhu, "On the relative importance of customer satisfaction and trust as determinants of customer retention and positive word of mouth," J. Target. Meas. Anal. Mark., vol. 12, no. 1, pp. 82-90, 2003.

[24] I. Geyskens, J.-B. E. M. Steenkamp, and N. Kumar., "A Meta-Analysis of Satisfaction in Marketing Channel Relationships?," J. Mark. Res., vol. 36, no. 1, pp. 223-228, 1999.

[25] S. Y. Lam, "Customer Value, Satisfaction, Loyalty and Switching Costs: An Illustration From a Business-to- Business Service Context," J. Acad. Mark. Sci., vol. 3, no. 32, pp. 293-311, 2004.

[26] T. C. Lin, "The Integration of Value-Based Adoption And Expectation-Confirmation Models: An Example of IPTV Continuance Intention," Decis. Support Syst., vol. 54, pp. 63-75, 2012.
Ind. Manag. Data Syst., vol. 115, no. 2, pp. 253269, 2015.

[14] M. S. Featherman and P. A. Pavlou, "Predicting Eservices Adoption: A Perceived Risk Facts Perceptive," Int. J. Human-Computer Stud., vol. 59, no. 4, pp. 451-474, 2003.

[15] J. C. Sweeney, G. N. Soutar, and L. W. Johnson, "The role of perceived risk in the quality- value relationship: a study in a retail environment," $J$. Retail., vol. 75, no. 1, pp. 77-105, 1999.

[16] D. L. G. Browne and J. Wetherbe, "Why Do Internet Users Stick With A Specific Web Site? A Relationship Perspective," Int. J. Electron. Commer., vol. 10, no. 4, pp. 105-141, 2006.

[17] H.-W. Kim, H. C. Chan, and S. Gupta, "Valuebased Adoption of Mobile Internet: An Empirical Investigation," Decis. Support Syst., vol. 43, no. 1, pp. 111-126, 2007.

[18] T. Zhou, "An empirical examination of continuance intention of mobile payment services," Decis. Support Syst., vol. 54, no. 1, pp. 1085-1091, 2013.

[19] T. Oliveira, M. Thomas, G. Baptista, and F. Campos, "Mobile Payment: Understanding the determinants of customer adoption and intention to recommend the technology," Comput. Hum. Behav., vol. 61, pp. 404-414, 2016.

[20] C. L. Miltgen, A. Popovič, and T. Oliveira, "Determinants of end-user acceptance of biometrics: integrating the 'Big 3' of technology acceptance with privacy context," Decis. Support Syst., vol. 56, pp. 103-114, 2013.

[21] N. K. Malhotra, Marketing Research: An Applied Orientation. 06 ed.).New Jersey: Pearson, 2009.

[22] Z. Peng and L. U. O. Fuzhou, "Research on Realtionships beetween Network Structure and

[27] C. A. de Matos and C. A. V. Rossi, "Word-ofmouth communications in marketing: a metaanalytic review of the antecedents and moderators," J. Acad. Mark. Sci., vol. 36, no. 4, pp. 578-596, 2008.

[28] D. F. Karya and A. N. I. Saputri, "Pengaruh Model Delon and McLean Terhadap Kepuasan Pengguna Pada Pengguna Aplikasi OVO di Surabaya," Natl. Conf. Ummah NCU, vol. 1, no. 1, 2020.

[29] T. T. Pham and J. C. Ho, "Technology in Society The effects of product- related, personal-related factors and attractiveness of alternatives on consumer adoption of NFC- based mobile payments," Technol. Soc., 2015, doi: 10.1016/j.techsoc.2015.05.004.

[30] K. Rouibah, P. B. Lowry, and Y. Hwang, "The effects of perceived enjoyment and perceived risks on trust formation and intentions to use online payment systems: New perspectives from an Arab country," Electron. Commer. Res. Appl., 2016, doi: 
10.1016/j.elerap.2016.07.001.

[31] H.-W. Kim, Y. Xu, and S. Gupta, "Which Is More Important In Internet Shopping, Perceived Price Or Trust?," Electron. Commer. Res. Appl., vol. 11, no. 3, pp. 241-252, 2012.

[32] J. L. Heskett, T. O. Jones, G. W. Loveman, E. W. Sasser, and L. A. Schlesinger, "Putting the ServiceProfit Chain to Work," Harv. Bus. Rev., vol. 72, no. 2, pp. 167-174, 1994.

[33] A. M. Chaabane and P. Volle, "Perceived Benefits Of Loyalty Programs: Scale Development and Implications For Relational Strategies," J. Of,
2010.

[34] P. Mahanani and D. F. Karya, "Loyalitas Pasien Rawat Inap Melalui Layanan BPJS Kesehatan (Studi pada RSI Jemursari Surabaya," Bus. Finance J., vol. 1, no. 1, 2016.

[35] D. F. Karya, "Customer Loyalty Perspective Developed From Customer Commitment," J. Appl. Manag. Bus. JAMB, vol. 1, no. 1, pp. 20-26, 2020.

[36] A. Bhattacherjee, "Understanding Information Systems Continuance: An ExpectationConfirmation Model," MIS Q., vol. 25, no. 3, pp. 351-370, 2001 